Grand Valley State University

ScholarWorks@GVSU

\title{
Games as 'Defining Moments' of the College Experience: The Impact of Reacting to the Past in French
}

\author{
David Eick \\ Grand Valley State University, eickd@gvsu.edu \\ Janel Pettes Guikema \\ Grand Valley State University, pettesj@gvsu.edu
}

Follow this and additional works at: https://scholarworks.gvsu.edu/mll_articles

Part of the Curriculum and Instruction Commons, and the Higher Education Commons

\section{ScholarWorks Citation}

Eick, David and Pettes Guikema, Janel, "Games as 'Defining Moments' of the College Experience: The Impact of Reacting to the Past in French" (2019). Peer Reviewed Articles. 2.

https://scholarworks.gvsu.edu/mll_articles/2

This Article is brought to you for free and open access by the Modern Languages \& Literatures Department at ScholarWorks@GVSU. It has been accepted for inclusion in Peer Reviewed Articles by an authorized administrator of ScholarWorks@GVSU. For more information, please contact scholarworks@gvsu.edu. 
eickd@gvsu.edu

pettesj@gvsu.edu

\section{Games as 'Defining Moments’ of the College Experience: The Impact of Reacting to the Past in French}

by David Eick and Janel Pettes Guikema

PHILOSOPHERS AND SCHOLARS have attempted to elucidate the power of play for centuries. In his 1795 Letters on the Aesthetic Education of Man, Friedrich Schiller posited the existence, innate in humans, of a play drive (Spieltrieb), which gives rise to artistic creation and whose full activation holds the key to the creation of a utopian society. In Homo Ludens (1938), Johann Huizinga similarly located this play instinct at the heart of human achievement in law, science, philosophy-indeed, civilization itself. Erik Erikson argued that play is essential for learning, human development, and even adult wellbeing. Play facilitates learning, according to Stuart Brown, by activating and creating new neural pathways between various brain centers involving cognition, emotion, and information retention. James Gee suggests that games are effective teaching tools, due to the ways in which students become the agents of their experience, assume new identities, experience ‘pleasant frustration' in taking on challenges, are motivated to expand their competencies, and in the end reap rewards for doing so. Similarly, Jesper Juul avers that games motivate us to learn by rewarding persistence in the face of repeated failure, making success feel deserved, because hard-won. For Frank Rose, the immersive pleasure of playful learning is the genetic adaptive remnant of the dopamine 
rush induced by successful foraging in the face of uncertainty. Finally, Mark Carnes argues that role-playing games can “transform college” by importing students’ competitive, subversive, and playful extracurricular proclivities into the classroom and intellectualizing them. College is a propitious moment for learning through role play, according to Carnes, inasmuch as students are already experimenting with new identities.

Carnes is the creator of Reacting to the Past (RTTP), a pedagogy used at over 350 colleges and universities in the United States and abroad, involving complex role-playing games centered around flashpoints in history ranging from ancient Athens to Title IX, when big ideas clash. In order to “win,” students must write effectively, speak volubly and cogently, read texts closely, collaborate, conduct library research, think both critically and creatively, solve problems, and take initiative-everything we have always labored to get them to do. In sum, RTTP enhances student engagement, develops multiliteracies, and promotes active learning.

RTTP has been used in disciplines from classics to STEM, but foreign-language instructors have been slow to tap its potential. ${ }^{1}$ First of all, because the published game materials are in English. ${ }^{2}$ Second, because most of the language-related tasks enumerated above are associated with the Superior level, according to the ACTFL Proficiency Guidelines, ${ }^{3}$ while our upper-level students are typically at Intermediate High, occasionally Advanced Low. To ask students to do these things is to court linguistic breakdown and discouragement. Yet through guidance and scaffolding, the motivation induced by the game format, and a great deal of time on task, students playing RTTP games are able to synthesize complex texts (interpretive mode of communication), sustain sophisticated arguments both in prepared speeches (presentational mode) and 
unstructured oral interactions (interpersonal mode), and opine on their own learning, all in the target language.

In an age of shifting priorities in higher education, with the humanities in crisis, language programs being eliminated, ${ }^{4}$ and the demographics of our classrooms evolving in challenging ways, we should experiment with new pedagogies that engage our students and make French relevant and exciting to them. In response to the 2007 MLA call for curricular reform, we argue that the integration of RTTP into our courses holds great promise for French programs seeking to surmount these challenges, unify their curricula, and thrive. This article describes three games that we run—entirely in French—in language, literature, and culture courses. It invokes a multiliteracies framework in arguing for their effectiveness, dispenses practical information for implementing games in the foreign-language classroom, and considers the learning experience from the students’ perspectives.

In the game Rousseau, Burke, and Revolution in France, 1791 (by Jennifer Popiel, Mark Carnes and Gary Kates), students don the roles of Louis XVI, Lafayette, and delegates to the Constituent Assembly in Paris. They collaborate-and clash—in attempting to create a constitution for France, two years after the fall of the Bastille. They were planning to adopt a constitutional monarchy until the king fled Paris with his family, only to be apprehended in Varennes. By inflaming public opinion, the king's treachery complicates the delegates' task. Conservatives invoke Burke’s $\underline{\text { Reflections on }}$ the Revolution in France (1790) to promote tradition and stability, while Jacobins cite Rousseau's Contrat social (1762) to situate sovereignty in the general will of the people. Both sides seek to persuade indeterminate characters to vote with them, via speeches, 
private conversations, and articles in the periodical press. All must contend with the Sans-Culottes, who are excluded from the proceedings, but nonetheless remain a vocal and menacing force. It is not uncommon for characters to disappear in this game as a result of crowd actions, just as historically many of the Constituent Assembly delegates fled into exile or were dispatched. In such an instance, the game master assigns a new role to the student, whose character is dramatically reincarnated as a member of the crowd. Braving the chaos, the president of the Assembly determines the agenda, which focuses on the appropriate role of the Church and on questions of equality, human rights, and legitimate political authority. As students reflect, debate, and write about these matters, tension mounts, while the invading Austro-Prussian forces attempt to restore the absolute monarchy and the Duke of Brunswick threatens to destroy Paris should harm befall Louis XVI.

In The Enlightenment in Crisis (Eick and Galbraith), students canvass the ideals of the Enlightenment as the Encyclopédie appears, one volume per year (and per class session), sparking intense interest and conversation among the learned reading public, generating controversy for its undermining of Church and State, and facing repression from these authorities. Sessions are run by Mme Geoffrin, whose salon hosts philosophes, artists, scientists, and statesmen. Inspired by Dena Goodman’s feminist history of the salon, the game emphasizes the role of women in shaping the Enlightenment, as Mme Geoffrin grants philosophes a forum in which to air their ideas and rub shoulders with social elites (Voltaire weighs in from exile in letters that are read aloud in the salon). Meanwhile, figures embodying the Catholic Counter-Enlightenment read the Encyclopédie closely in order to locate and denounce heresy and sedition, which 
are often veiled in irony, to fool the royal censors. Rousseau becomes increasingly vocal in denouncing the Enlightenment and women's leadership in it, delighting its enemies, who attempt to divide and conquer the philosophes. All characters seek to enhance their crédit, an amalgam of financial and symbolic capital, through correspondence, essay contests sponsored by academies, courting grandees, or supporting the careers of up-andcoming writers. In this way, the game also embodies Antoine Lilti's depiction of the salon, at odds with Goodman's, as a space where social ambition outweighed the pursuit of the Enlightenment. In the game’s climax, characters must decide whether to risk their hard-won crédit and support the Encyclopédie, bringing public opinion, an emerging political force in 1750s France, to bear on the Monarchy as it decides whether or not to suppress the work and carry out the death penalty against its authors. The Enlightenment game conveniently sets up the French Revolution game and reduces the number of pregame preparation sessions necessary, though both games can stand alone.

In Modernism versus Traditionalism (McKay et al.), characters like Monet, Van Gogh, Berthe Morisot, Renoir, Mary Cassatt, Toulouse-Lautrec, Cézanne, Gauguin, Pissarro, and Seurat confront the hidebound Académie de Beaux-Arts and its strictures against innovation. With the newly-erected Eiffel Tower in the backdrop, the game culminates in the 1889 Exposition universelle, an art show organized by students. This is a great venue for showing RTTP to administrators and colleagues, who upon arrival receive short role sheets as rich art collectors and are instructed to engage with artists, critics, and dealers. They tend to be impressed by our students' knowledge and intellectual energy, especially since it is in French. The game requires no artistic knowledge on the part of the instructor. The instructor's manual and student player 
manual include setup materials that prepare students and the game master sufficiently. Students develop proficiency to describe and even debate, vehemently and with conviction, the aesthetic merits of visual images and the role of art in society.

Learning through RTTP challenges students to engage in ways not required or even possible in a more traditional learning environment, where they too often sit passively while content is delivered by the instructor. Viewed within a multiliteracies framework (New London Group), learning through RTTP is just the opposite: a process of discovery, learner-centered, dynamic, and interactive, where learners make connections between form and meaning through interpretation and creation of text—oral, visual, audiovisual, and digital (Paesani et al.). RTTP centers around texts, as students interpret meaning from authentic documents (the Encyclopédie, Impressionist paintings, and other primary sources) and create their own texts in the form of speeches, essays, treatises, articles, pamphlets, and letters. This dynamic process requires learners to draw on resources—linguistic, schematic, visual—they have encountered and appropriated in previous life and learning experiences, known as “available designs," as they create new text through “meaning design” (New London Group). This process of transformation, where learning is creative, dynamic, collaborative, and without determined limit, is at the heart of RTTP pedagogy. ${ }^{5}$

Within a multiliteracies framework, four essential pedagogical acts allow us to maximize RTTP for language development and to enable effective engagement with texts: situated practice, overt instruction, critical framing, and transformed practice (Cope and Kalantzis; Kern; New London Group). These overlapping, nonlinear components of a multiliteracies pedagogy are integral to RTTP. Situated practice involves spontaneous, 
experiential learning where students are immersed in activities that allow them to use knowledge to make comparisons and associations and to explore new texts. Overt instruction creates a space for the instructor to provide scaffolded learning activities, provide explicit explanation, and guide learners in understanding language conventions and, in the case of RTTP, text-specific items or the historical context of the game. In critical framing activities, learners "analyze and question the meaning, importance, and consequences of what they learn” (Paesani et al. 38). Finally, transformed practice involves the application of knowledge and understanding to create new texts and personalize learning, which might be focused on appropriateness for real-world contexts or instead on creativity and innovation.

A pedagogy of multiliteracies is the quintessence of active learning. In their introduction to Playing to Learn with Reacting to the Past, Hagood et al. contrast the active nature of an RTTP class session with passive note-taking. To be sure, students may take notes in a game, but they will process them cognitively, with a view toward countering the arguments presented in a speech by their adversaries in order to persuade characters of the rightness of their own views, which is an example of transformed practice. RTTP compels participation of all students and makes it difficult for students to disengage. Hagood et al. even suggest that engagement is a "social requirement" (3). Indeed, students need their peers to be productive in order to prevail: in the French Revolution game, factions need contributors to write articles for their newspapers; in the Enlightenment game, aspiring philosophes need the patronage of grandees in the form of speeches and letters; in Modernism versus Traditionalism, prolific artists need enterprising dealers and vice versa. At minimum, there is a certain peer pressure among 
students for their faction mates to attend class in order to vote for their victory objectives. Hagood et al. speak of "high and nearly inexplicable levels of student participation and commitment to class sessions using RTTP games” (160). It is the essence of transformed practice when students apply knowledge and understanding in order to make impassioned and convincing pleas to persuade others, or when they describe their artwork to potential buyers in an effort to sell the most paintings and win the game.

Our intention in what follows is to give instructors an idea of what is involved in running an RTTP game and to help them envisage how it might work in nearly any course. This is not intended as a substitute for RTTP instructor training workshops, where, in addition to learning how to become a "game master," instructors often play condensed versions of games, for it is valuable for us to garner a sense of what the experience is like for our students: fun, but also demanding, occasionally tense, and so different from a typical classroom.

The instructor's manual, available for free download behind a password-protected fire wall, provides the roadmap and all materials one needs to run a game, such that one need not be an expert in its content. The first stage in a game is setup. This period might require several class sessions-usually two to five, depending on the game, student learning goals, and time constraints. First, students acquire knowledge of the game's historical and cultural context and the ideas in conflict. They glean this information via the student player manual, or game book, which includes essays by the game's author(s) as well as primary sources, such as, in the French Revolution game, excerpts from Montesquieu, Voltaire, the Déclaration des droits de l'homme et du citoyen, and the August 1789 Decrees abolishing feudalism and aristocratic privilege, as well as passages 
from Burke's Reflections on the Revolution in France, which informs the arguments of the conservatives. Students are also required to read in its entirety Rousseau's Contrat social, the bible of the Jacobins and Sans-Culottes. Students normally read these texts in the original French (except for Burke), which requires not only more time on task, but also careful scaffolding by the instructor.

Overt instruction is also a key component of setup. The instructor guides students in their development of the background knowledge necessary to participate in the game. Instructors might give a presentation of key concepts, in addition to providing opportunities both to practice the use of this knowledge and to make form-meaning connections. Instructors can use instructional conversations (Tharp and Gallimore), an example of critical framing wherein they pose open-ended questions and provide feedback, to help learners analyze and apply background knowledge as they investigate the game's historical and cultural context, characters, and core texts. Students may be assessed for their mastery of this material, individually or in factions as a way of building group cohesion, with quizzes included in their player manuals or by assessments devised by the instructor. Students tend to pay attention when the instructor points out that their grasp of this information may be the difference between winning and losing the game.

In addition to the historical and intellectual backdrop, during setup students also learn about the character they have been assigned to play. After casting the game, the instructor distributes role sheets, each of which includes the character's biography, victory objectives and, often, secrets. Students must learn as much as they can about their role in order to play effectively and truly get into character. Researching the other characters is also competitively advantageous. Library research training can be added to 
the setup. We often bring in a librarian to help our students find sources of information on their and other characters and on aspects of history pertinent to the game. Students tend to be more exercised than usual about library research, given the competitive advantage afforded by information from scholarly sources.

Finally, setup is crucial for RTTP games in the FL classroom. These games present a tall order for our students: while most possess Intermediate-level oral competency, their victory objectives require them to execute Advanced- and even Superior-level tasks. The most important of these is to sustain complex argumentsorally, in formal speeches and informal conversation, and in writing, usually journalistic and epistolary — in order to persuade characters to side with them. The latter, conversely, must rehearse all factions’ arguments before indicating in detail which persuaded them and why.

In the Enlightenment game, Encyclopédie editor Diderot must make a compelling case for the values of the Enlightenment in order to elicit the support of powerful grandees like Mme Geoffrin, who hosts the influential salon in which the game's action unfolds, and to convince wavering philosophes under fire from the Monarchy and the Church to remain committed to the project. Similarly, in the French Revolution game, Lafayette, Danton, and their acolytes fiercely contest philosophical ideas about equality and citizenship, as well as the related practical question of who should be allowed to bear arms and join the National Guard, in a debate whose outcome can determine the winners and losers of the game, not to mention the fate of France.

To equip students to sustain this level of discourse in French, during game setup the instructor engages in overt instruction to support vocabulary development and 
facilitates situated practice through collaborative semantic mapping, interpersonal tasks focused on developing discourse strategies, and opportunities for guided textual interpretation. To set up Modernism versus Traditionalism, in which students need context-specific terminology to discuss and critique nineteenth-century French paintings, the instructor provides students a list of technical terms and guides them through the process of describing the content, style, and technique of specific works, using Édouard Detaille’s "Le rêve” as an example.

We wish to emphasize that when playing a game in a foreign language, students need extra time to embody their characters and find their unique voices. We encourage adding one or two days to the setup indicated in the game manuals. It is easy to design activities, whether informal or highly structured, in which students interact in character, determine intellectual and social affinities and differences, stake common ground with their faction mates, tell their foes precisely why they are wrong, and expound the most convincing arguments to inveigle the undecided, who must scrutinize the merits of the various arguments presented to them—all of this, before the game even begins. This extra setup time is crucial in adapting RTTP pedagogy for foreign languages. Fortunately, the need for extra setup in the FL classroom is also an opportunity for students to engage in a great deal of contextualized, meaningful, and lively communicative practice.

As in setup, during the game itself we similarly recommend that, in adapting RTTP for languages, extra time be allotted during the game to assist students in accomplishing the high-level linguistic tasks which make up their objectives. At the beginning of every session, we devote at least ten minutes for characters to mingle and converse, whether informally or on a topic provided, perhaps related to the business on 
the agenda for that day's session. In addition, instructors can spread one game session over two class periods. For example, the French Revolution game manuals usually indicate two items on the agenda for a given session. Instead, a full session can be devoted to each. Thus, whereas the Revolution game normally takes six class periods, in a French course it could easily take nine. This will be time well spent on extra speaking practice and scaffolding for challenging tasks. In our experience, students have never tired of a game- - in fact, they often express afterward that the game should have lasted longer - though they do become tired from the hard work they put into it.

Once a game starts, students with leadership roles set the agenda and run the classroom proceedings, while the instructor becomes the game master, sort of a coach and referee, an unobtrusive but authoritative presence on the sidelines, while the students are vocal and active. In the parlance of multiliteracies, students engage in critical framing, analyzing and opining on texts, and situated practice, applying what they have learned from texts and previous interactions and experiences. In $\underline{\text { Modernism versus }}$

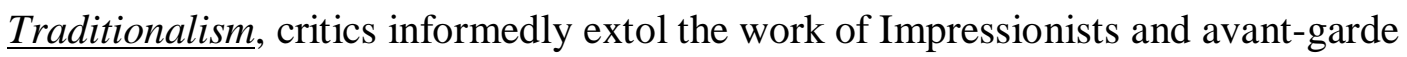
artists like Pissarro, Seurat, and Gauguin, while disparaging, again in precise terms, paintings favored by the traditional Académie. Game sessions involve debates, speeches, and faction meetings, in which students strategize. For example, members of the Académie debate the merits of painters and decide whom to admit to their elite ranks. Game sessions are inherently communicative, involving all three modes of communication: interpretive, interpersonal, and presentational. Between sessions, outside of class, students write for and/or edit faction newspapers, whose quality can give them an edge in the game; compose and practice speeches; read primary and secondary texts; 
and perhaps conduct library research pertinent to the agenda of the next session. They also frequently take initiative outside of class, both to meet in person and to communicate in character on various social media platforms. We have had success with Slack, in both web-based and application formats, which allows instructors to assign, track, and grade students’ communication online.

Games tend to have a narrative arc and reach a crescendo or climax in the final session. After considerable machinations, Modernism versus Traditionalism culminates with an art show, organized by the students, at the 1889 Exposition universelle. Winners and losers are determined in the last session: Which of the rival art dealers will recruit saleable artists and make more money? Will Van Gogh sell a painting?

Games can end in ahistorical outcomes, but still within "the corridor of historical plausibility” (Galbraith 380). RTTP is not about simulations. Instead, there is learner agency and contingency. Hard work and a roll of the die can alter the course of events. History professors may shudder at ahistoricities, but the historical record is set straight in the game's postmortem. After the game has ended, to culminate the experience and further deepen learning, instructors can assign a reflective paper in which students describe their favorite moments in the game, inform the instructor regarding conversations or work about which s/he might not otherwise know, indicate which scholarly sources were useful as they played, describe where the game departed from history, describe their proficiency development, and reflect on the overall experience. The reflective paper is another example of "transformed practice,” in which students apply what they have learned, explaining actions and consequences and reconciling them 
with historical events. It is often at this moment that students realize how much they have learned and how hard they have worked.

Following the game, at least one class session should be dedicated to a postmortem. Students can reconcile with classmates with whom they may have clashed during the game. They can share their secret objectives and one piece of information they believe everyone should retain about their character. Instructors might offer more explicit instruction to ensure that students have a firm grasp on how the game may have deviated from historical events (the instructor's manual provides helpful materials for a more traditional postmortem lecture). As students have been immersed in the role they played, they are usually motivated to find out where their version of history deviated from actual events. It is also remarkable to see how interested they have become in the subject.

Following the postmortem, we often assign a traditional research paper, asking students to investigate topics that piqued their interest during the game or the postmortem lecture. Engagement and motivation continue to be high even during this stage. Students have connected personally with the subject, researching and writing on such interdisciplinary topics as Encyclopédie co-editor D'Alembert's contributions to calculus (by a math/French double major), inoculation and the Enlightenment (by a premed/French double major), violence in popular songs during the French Revolution, and the effects of trauma on children during the Revolution (by a psychology major).

This description of how to run a game may initially appear daunting. While we are enthusiastic proponents of RTTP for foreign languages, we do not wish to gloss over the challenges it presents. We reiterate that much time is required in order for it to work. Instructors may have to adjust content and sacrifice some broader "coverage." It also 
takes time for instructors to become familiar with a game's materials and mechanics. However, instructors do not need to be experts on its content. After running a game once or twice, one learns how it works and does not need to invest as much time in planning. The other primary challenge of RTTP is that it is quite different from a "normal" class. Students will initially be confused by, and may even resent, having to direct class sessions and not being told exactly how to accomplish their victory objectives. Instructors may find it difficult to keep silent, especially when learners are discoursing imperfectly in terms of content or linguistic accuracy. It takes a few games for instructors to know when to intervene (infrequently) and when to just let go (usually) of the reins. In sum, both students and instructors may be discomfited by this more extemporaneous way of learning. RTTP relies on the willingness of students and instructors to take risks and be open to non-traditional models of classroom discourse and learning.

Assigning roles can present challenges, but these are easily turned into opportunities. While some argue for random role assignments to avoid bias, we practice deliberate role allocation depending on several factors, among them oral proficiency, personal interests, and, in some cases, leadership and organizational qualities. Schaller supports deliberate role allocation to ensure that more extroverted students with stronger proficiency skills are assigned primary roles which involve advanced linguistic functions (see the instructor's manual). Conversely, students who are less proficient or confident may be assigned less demanding roles. Instructors can also consider assigning a key role to diffident students in order to give them a chance to shine and fulfill potential hitherto untapped. Students' majors can also be a factor. In the Enlightenment game, the role of Mme Geoffrin might be given to a human resources major; Diderot, to a philosophy or 
literature major; publisher Le Breton, to a business major; Rameau, to a music major; Dr. Tronchin, to a student in health sciences. In the Revolution game, the role of Alquier can be assigned to an economics major. Meanwhile, students who are fans of the musical Hamilton covet the role of Lafayette. Obviously, instructors need to know their students, but this is not always possible. We emphasize that students at varying levels of proficiency can benefit from and enjoy RTTP games. This pedagogy thus offers a unique approach to differentiated learning.

Another potential challenge is enrollment in upper-level French courses. Most games require eleven or twelve students in order to run effectively. What if enrollments are low? We have employed curricular solutions such as "stacking" courses at the 300 and 400 levels to provide a 2-in-1 model to populate our courses. We also offer bilingual courses in which students may register for credit in French or in another discipline or program such as English or Honors. In this configuration, large-group deliberations take place in English, but students of French speak French to each other and are cast in factions together. In addition, outside of class they write all papers in French and read the game's core texts in the original.

Resources and support are available to help instructors confront these and other challenges. The RTTP Consortium website provides information in addition to materials for a variety of games. An active and supportive online community connects in the Reacting Faculty Lounge on Facebook, answering questions and sharing successes and difficulties. For foreign language instructors, we are preparing a resource manual and template for setting up and running games at multiple levels of the curriculum and in a variety of courses. Finally, while some enterprising instructors jump right in, we 
recommend participating in one or more of the many RTTP training workshops offered around the country.

As mentioned above, what appear to be challenges can in fact be advantages. For example, instructors may wonder how RTTP might fit into their curriculum. The answer is, almost anywhere, as the games are robust, adaptable, and effectively address all of ACTFL's World Readiness Standards. ${ }^{6}$ In a more skills-based course focused on writing, instructors can emphasize the writing component of the game. In a literature course, reading and understanding original sources (Rousseau, the Encyclopédie, Mme de Graffigny) might be prioritized. Similarly, in a civilization course, a game’s cultural significance can be emphasized over linguistic development, although proficiency development is arguably unavoidable. Games include assignments which instructors can modify, reduce, or supplement, in accordance with a course’s learning objectives.

Instructors also sometimes worry if a student plays a game more than once. In fact, it is helpful to have veterans who know the workings of a game and can help carry the novices. The student will benefit by approaching the content from a different perspective through the eyes of a different character. The only potential caveat is leaking key information: students must promise not to reveal their previous characters' secrets.

What do students think about playing RTTP games in French? From an instructor's standpoint, we know the pedagogy has rigor and provides historical and meaningful context for learning. However, it certainly behooves us to listen to what students have to say about the games’ effectiveness for learning a foreign language. We administered qualitative surveys immediately after the postmortem in seven sections of 300- and 400-level French courses. The survey questions that elicited the following 
responses were open-ended, asking about the game’s overall benefits for their learning. The first few quotes point to the potential of play to transform and even transcend language learning:

S1: It is impossible to overstate what a positive experience I had playing this game. In the five years of my college education, this has been the most engaging and exciting course I have taken, and I am confident that I will remember it as one of the defining moments of my undergraduate career.

S2: RTTP is such an all-encompassing way to not only work on your French but to also learn about another content area. We were using our French to learn about the Enlightenment instead of simply learning about the language. It's like a twofor-one deal.

S3: The game was a great way to improve my confidence. It was fun to take on a role and form alliances all while practicing French.

S4: I was able to speak more quickly without worrying about being wrong. S5: I feel like it made me come out of my comfort zone and really try to look up new words that I did not know and find new ways to explain myself. S6: I became less dependent on how to say things and just said them. S7: My confidence in speaking French skyrocketed without me even thinking about it.

These comments not only highlight that RTTP goes beyond just learning about the language, they also point to an increase in confidence and tolerance for ambiguity. Describing an ESL class involved in an RTTP game, Carnes argues that "as students focused on persuading peers, their inhibitions evaporated” (140). In other words, students 
gain confidence as they become immersed in the game, thinking more about how to accomplish their victory objectives through communication than about the correct pronunciation or finding "le mot juste." This is not to say that accuracy does not matter. Students often demonstrate an awareness of grammatical and lexical error and employ strategies to avoid communication breakdown, including self-correction, reformulation, self-talk, asking for clarification, or consulting peers and instructor. This emerging strategic competence (Canale and Swain) is an indisputable benefit of the intense, immersion-like learning environment that requires sustained effort, negotiation, and thinking in the target language.

Along with increased confidence, students also develop a more sophisticated sociolinguistic competence (Canale and Swain) through spontaneous interactions with their peers in character. Student comments point to this development:

S8: In order to play the game, you had to know how to work your way around what you wanted to say if you didn't necessarily have the words. You had to really think about what your person would say or do in each situation! S9: I had to understand what others were saying so that I could react appropriately.

S10: I had a very strange suspension of reality while playing the game that made me incredibly empathetic to people counter enlightenment, even though those ideas didn't correspond at all with my personal beliefs. I think it helped me take a step back and see the motivation behind real people’s ideas and actions.

These comments highlight an increased awareness of language use and an emerging awareness of identity — they are playing the game as someone else who, in most 
instances, was a real person. Students must negotiate meaning from the vantage point of someone from another time and place, of a different social status, with religious, social, or political views different from their own. In order to do this effectively, students must discover as much as possible about their character. Even in games played in English, it can take several sessions before students begin to feel comfortable in their new skin. In a foreign language, the experience is much richer.

As noted above, most tasks in RTTP games are at the Advanced and Superior proficiency levels (ACTFL), requiring students to argue, persuade, defend opinions, hypothesize, and speak extensively about complex and abstract topics. Many foreign language majors do not reach the Advanced level until they are nearly finished with the degree, if they reach it at all, unless they have spent at least a semester studying abroad. However, we are beginning to see, both anecdotally and particularly in Schaller's pioneering work on implementing RTTP games in French, that students are indeed capable of higher levels of proficiency and engagement during games as they gain experience in all three modes of communication-interpretive, interpersonal, and presentational—-through researching events and people, strategizing with faction members, attempting to persuade (through informal conversation) those with opposing views, writing essays, letters, and treatises, and delivering speeches.

In addition to the linguistic and cultural benefits, a growing body of research points to more general benefits for a generation of digitally-native students who spend prodigious amounts of time using digital technology and gazing at screens. Stroessner et al. compared Reacting and non-Reacting classes and found that students who played games demonstrated increased self-esteem and empathy by the end of the semester, in 
addition to enhanced verbal and rhetorical skills. The National Research Council defined “deeper learning” as:

[T] he process through which an individual becomes capable of taking what was learned in one situation and applying it to new situations (i.e., transfer). Through deeper learning (which often involves shared learning and interactions with others in a community), the individual develops expertise in a particular domain of knowledge and/or performance [...]. The product of deeper learning is transferable knowledge, including content knowledge in a domain and knowledge of how, why, and when to apply this knowledge to answer questions and solve problems. $(5-6)$

These competencies_critical thinking, problem-solving, collaboration, communication, and self-direction—are the reasons why Reacting games work, as they allow students to exercise agency, develop and sate their curiosity, and discover new but abiding intellectual interests, all the while following the threads of history in pursuit of their victory objectives.

RTTP comports indisputable benefits for the French classroom, particularly with regard to proficiency development, fluency, and confidence. Moreover, RTTP fosters community-building, leadership, and teamwork. Carnes argues that it helps develop "global citizens," "inculcating morality and empathy" for others who think differently (12). ${ }^{7}$ Reacting to the Past is a transformative pedagogy that provides a "playful" yet rigorous alternative to mechanical learning and knowledge transmission. Students are guided through a process of deeper learning as they make comparisons, apply knowledge, 
ask questions, collaborate, consult primary sources, reflect on learning, and ultimately, construct new meanings.

Admittedly, this article may come across as a breathless commercial or cultish enthusiasm for a pedagogical fad. Yet no less an authority than Jose Bowen has stated that RTTP has the potential to "revive teaching.” Carnes cites a Grand Valley Lanthorn article to describe the impact that playing a Reacting game can have on students, one of whom gets the last word here: “After playing the French Revolution game, Joe Hogan, a student at Grand Valley State University (Michigan), wrote that RTTP revealed to students 'their own authentic capacity to effect real change in culture- to have a vision for the world and be bold enough to enact it” (242-43).

GRAND VALLEy STATE UNIVERSITy (MI)

\section{Notes}

${ }^{1}$ To our knowledge, Schaller was the first to implement RTTP in foreign languages. Her groundbreaking article focuses on the French Revolution game. We wish to thank her for her generosity and collaboration.

${ }^{2}$ We are in the process of translating and adapting game materials for the French classroom. These can be obtained on the Reacting to the Past Consortium website$<$ reacting.barnard.edu/the-curriculum $>$ — or by contacting the authors.

${ }^{3}<$ actfl.org/publications/guidelines-and-manuals/actfl-proficiency-guidelines2012>. 
${ }^{4}<$ chronicle.com/article/Enrollment-in-Most/242766> and <insidehighered.com/news/2018/03/13/faculty-members-wisconsin-stevens-point-reactplan-cut-13-majors>.

${ }^{5}$ While RTTP is "low-tech” and focuses less on emerging and digital literacies associated with multi-modal communication, digital tools and resources can play a role. Learners develop information and digital literacies as they research characters and events, consulting primary and secondary sources both online and at the bricks-and-mortar library. We have also successfully integrated the use of digital group chats through the online collaboration hub $\underline{\text { Slack }}$ as well as video reflective journaling using $\underline{\text { FlipGrid. }}$.

${ }^{6}<$ actfl.org/sites/default/files/publications/standards/WorldReadinessStandardsforLearningLanguages.pdf>.

${ }^{7}$ RTTP received the 2004 Theodore Hesburgh Award for pedagogical innovation and has been highlighted in such publications as $\underline{\text { Change Magazine, the Chronicle }}$ $\underline{\text { Review, the New York Times, the Chronicle of Higher Education, and the Christian }}$ $\underline{\text { Science Monitor }}$ <reacting.barnard.edu/reacting-home>.

\section{Works Cited}

Bowen, Jose. "Reacting to the Past Will Revive Your Teaching.” Teaching Naked. 15 July 2016. <Teachingnaked.com/reacting-to-the-past-with-revive-your-teaching>.

Brown, Stuart. Play: How It Shapes the Brain, Opens the Imagination, and Invigorates the Soul. Avery, 2009.

Canale, Michael, and Merrill Swain. "Theoretical Bases of Communicative Approaches to Second Language Teaching and Testing.” Applied Linguistics 1.1 (1980): 1-47. 
Carnes, Mark. Minds on Fire. Harvard UP, 2014.

Cope, Bill, and Mary Kalantzis, ed. The Powers of Literacy: A Genre Approach to Teaching Writing. UP of Pittsburgh, 1993.

\section{Eick, David, and Gretchen Galbraith. The Enlightenment in Crisis: Diderot's} Encyclopédie in a Parisian Salon, 1750-?

Erikson, Erik. Childhood and Society. Norton, 1963.

Gee, James. What Video Games Have to Teach Us About Learning and Literacy. Palgrave McMillan, 2003.

Galbraith, Gretchen. “'I Had Almost Forgotten I was in a Classroom Setting’: Reacting to the Past and Engagement with Historical Thinking.” The Role of Agency and Memory in Historical Understanding: Revolution, Reform, and Rebellion. Ed. Gordon Andrews and Yosay Wangdi. Cambridge Scholars, 2017. 380-99.

Goodman, Dena. The Republic of Letters: A Cultural History of the French Enlightenment. Cornell, 1994.

Hagood, Thomas Chase, C. Edward Watson, and Brittany M. Williams. "Reacting to the Past: An Introduction to its Scholarly Foundation.” Playing to Learn with Reacting to the Past: Research on High Impact, Active Learning Practices. Ed. C. Edward Watson and Thomas Chase Hagood. Palgrave Macmillan, 2018. 1-16. Hagood, Thomas Chase, Naomi J. Norman, Hyeri Park, and Brittany M. Williams. "Playing with Learning and Teaching in Higher Education: How Does Reacting to the Past Empower Students and Faculty?” Playing to Learn with Reacting to the Past: Research on High Impact, Active Learning Practices. Ed. C. Edward Watson and Thomas Chase Hagood. Palgrave Macmillan, 2018. 159-92. 
Huizinga, Johann. Homo Ludens: Proeve Ener Bepaling Van Het Spelelement Der

Cultuur. Wolters-Noordhoff, 1938.

Juul, Jesper. The Art of Failure: An Essay on the Pain of Playing Video Games. MIT, 2013.

Kern, Richard. Literacy and Language Teaching. Oxford UP, 2000.

Lilti, Antoine. Le monde des salons: Sociabilité et mondanité à Paris au XVIIIe siècle. Fayard, 2005.

McKay, Gretchen, Nicolas Proctor, and Michael Marlais. Modernism versus

Traditionalism: Art in Paris, 1888-1889. Reacting Consortium, 2018.

MLA Ad Hoc Committee on Foreign Languages. "Foreign Languages and Higher Education: New Structures for a Changed World.” Profession (2007): 234-45.

New London Group. “A Pedagogy of Multiliteracies: Designing Social Futures.” Harvard Educational Review 66.1 (1996): 60-92.

National Research Council. Education for Life and Work: Developing Transferable Knowledge and Skills in the 21 $1^{\text {st }}$ Century. National Academies, 2012.

Paesani, Kate, Heather Willis Allen, and Beatrice Dupuy. A Multiliteracies Framework for Collegiate Foreign Language Teaching. Ed. Judith Liskin-Gasparro and Manel Lacorte, Pearson, 2015.

Popiel, Jennifer, Mark Carnes, and Gary Kates. Rousseau, Burke, and Revolution in France, 1791. $2^{\text {nd }}$ ed. Norton, 2015.

Rose, Frank. The Art of Immersion: How the Digital Generation Is Remaking Hollywood, Madison Avenue, and the Way We Tell Stories. Norton, 2012. 
Schaller, Peggy. "Can (Role-)Playing the French Revolution en français Also Teach the Eighteenth Century?” Digital Defoe: Studies in Defoe \& His Contemporaries 4.1 (2012): 41-60.

Schiller, Friedrich. Über die ästhetische Erziehung des Menschen. 1795. Schillers Werke 20. Ed. Julius Petersen et al. Hermann Böhlaus Nachfolger, 1943.

Stroessner, Stephen, Laurie Susser Beckerman, and Alexis Whittaker. “All the World's a Stage? Consequences of a Role-Paying Pedagogy on Psychological Factors and Writing and Rhetorical Skill in College Undergraduates.” Journal of Educational Psychology 101.3 (2009): 605-20.

Tharp, Roland, and Ronald Gallimore. Rousing Minds to Life: Teaching, Learning, and Schooling in Social Context. Cambridge UP, 1988. 